\title{
An index to evaluate the fluvial habitat degradation in lowland urban streams
}

\author{
Joaquín Cochero ${ }^{\mathrm{a}, \mathrm{b}, *}$, Agustina Cortelezzi ${ }^{\mathrm{b}, \mathrm{c}}$, Alan Santiago Tarda $^{\mathrm{a}, \mathrm{b}}$, Nora Gómez ${ }^{\mathrm{a}, \mathrm{b}}$ \\ a Instituto de Limnología “Dr. Raúl A. Ringuelet”-Facultad de Ciencias Naturales y Museo-Universidad Nacional de La Plata, 1900 La Plata, Argentina \\ b CONICET-Consejo Nacional de Investigaciones Científicas y Tecnológicas, Argentina \\ c Instituto Multidisciplinario sobre Ecosistemas y Desarrollo Sustentable (UNCPBA, Tandil), Argentina
}

\section{A R T I C L E I N F O}

\section{Article history:}

Received 22 January 2016

Received in revised form 20 June 2016

Accepted 29 June 2016

\section{Keywords:}

Monitoring

Riparian zone

River banks

Urbanization

Pampean streams

\begin{abstract}
A B S T R A C T
The objective of the present article is to propose an index that allows the assessment of the fluvial habitat quality in lowland streams that run through urbanized areas, by the use of metrics related to the quality of the watercourse, the river banks, the riparian zone and the fluvial geomorphology. The metrics retained in the index (USHI, Urban Stream Habitat Index) include the cover percentage and quality of the aquatic vegetation; the main features of the river banks; the presence of exotic trees, of litter, of permanent structures (such as buildings) in the riparian zone and other major geomorphological alterations, such as dredging or channelization. The index is related to physical-chemical parameters that are linked to water quality, the imperviousness of the watershed and to other biotic descriptors, particularly the macroinvertebrate and diatom assemblages. The values of the index for the sites in the studied area revealed that $41.2 \%$ have a bad or very bad habitat quality, $27.8 \%$ a moderate habitat quality, while $31 \%$ have a good or very good habitat quality. The main issue detected in the studied sites involved the dredging or partial channelization of the reaches. Unlike other indices that evaluate the quality of the physical habitat through the use of the diatoms or macroinvertebrate communities, the USHI can be interpreted as a measure of the overall quality of the habitat, and uses indicators that do not require the identification of taxa, making it more accessible to non-specialists. Therefore it provides with a tool to evaluate the fluvial habitat quality of lowland streams that can be easily applied, particularly by professionals that take part in the management and decision making process regarding urbanized watersheds.
\end{abstract}

(c) 2016 Elsevier Ltd. All rights reserved.

\section{Introduction}

The continued growth of the human population and the conversion of natural landscapes to urban uses have resulted in the degradation of ecosystems worldwide. Urbanization can dramatically impact watershed health through increased runoff from impervious surfaces, changes in sediment delivery, and increased pollutant and nutrient loads from nonpoint sources (Mayer et al., 2010; Yannopoulos et al., 2015; Valipour et al., 2015). These issues have led in the last decades to an intensification of efforts to develop methods to assess not only the water quality but the fluvial habitat as well, including the alluvial valley, the fluvial terraces, the riparian

\footnotetext{
* Corresponding author at: Instituto de Limnología "Dr. Raúl A. Ringuelet"-Facultad de Ciencias Naturales y Museo-Universidad Nacional de La Plata, 1900 La Plata, Argentina.

E-mail address: jcochero@ilpla.edu.ar (J. Cochero).
}

zone and the subterranean aquifer to which the river is connected to (Ordeix et al., 2012).

The aquatic habitat can be defined as the physical, chemical and biological characteristics that provide an environment for the biota (Jowett, 1997). Characterizing the physical structure and assessing the habitat quality of rivers is becoming more important in the context of environmental planning, appraisal and impact assessment (Raven et al., 2002). The fluvial habitat is affected by the features of the water body and the surrounding topography, and the structure and composition of the biological communities are related to the quality and quantity of available habitats (Aadland, 1993; Callow and Petts, 1994; Bortone, 2005; Borja et al., 2009).

A large variety of methodologies have been proposed to characterize the fluvial habitat or some of its components, in response to diverse environmental goals. These were implemented mainly for European (LAWA, 2000; Raven et al., 1998; Buffagni et al., 2004; Pedersen and Baattrup-Pedersen, 2003; Bonada et al., 2002; Munné et al., 2003; Pardo et al., 2002) North American (Barbour et al., 1999) 
and Oceanian (Davies et al., 2000; Parsons et al., 2004; Jansen et al., 2005; Brierley et al., 2005) water bodies.

In South America some of these indices have been translated and/or adapted for their proper use (e.g. Segnini and Chacón, 2005; Miserendino et al., 2008; Kutschker et al., 2009; Gualdoni et al., 2011; Villamarín et al., 2014), and some regional indices, although very scarce, have been developed to assess the habitat quality of specific habitats such as estuaries (Gómez and Cochero, 2013). However, due to the lack of a standardized methodology to assess the hydromorphological quality that would allow the comparison of physical characteristics of rivers among regions or at continental level (e.g. Raven et al., 2010), the application of "allochthonous" indices can be impracticable.

The Pampean streams in Argentina are characterized by their low water velocity, low slope $(1 \mathrm{~m} / \mathrm{km})$, reduced or no rithron, abundant clay and silt substrates, a riparian vegetation dominated by grasslands and a diverse and abundant aquatic vegetation (Giorgi et al., 2005). Despite previous efforts to implement existing habitat indices (Barbour et al., 1999; Raven et al., 2002) the variables they include are not necessarily applicable for Pampean streams. For instance, the habitat index proposed by Barbour et al. (1999) for low-gradient streams considers ten river channel features, the first four being the sediment characteristics (epifaunal substrate, pool substrate characterization, pool variability and sediment deposition), while there are no parameters that consider the instream aquatic vegetation cover; in Pampean streams the habitat heterogeneity is usually the result of submerged vegetation rather than the result of different type and size of substrata (Giorgi et al., 2005), so the inclusion of this community to the index is of great importance.

The objective of the present study was to select and combine metrics related to the fluvial habitat of Pampean streams into an index that allows the assessment of the habitat detriment in lowland urbanized streams. This index aims to provide with a tool to evaluate the fluvial habitat quality of lowland streams that can be easily applied, particularly by those professionals that take part in management and the decision making process in urbanized watersheds, without the need of specialized sampling of biotic communities.

\section{Materials and methods}

\subsection{Study area}

Habitat data from 39 sampling sites was collected in different seasons from 2008 to 2015, for a total of 158 cases (Table 1). Sampling sites were located near the cities of Buenos Aires ("Matanza-Riachuelo" basin, 2008-2014), La Plata ("El Gato" basin, 2014-2015; "Baldovinos-Don Carlos-Martin" basin, 2008); and Tandil ("Langueyú" basin, 2012) (Fig. 1). In each of these sites, physical-chemical, biological and habitat data was collected simultaneously to test their correlation to the index.

\subsection{Physical-chemical data}

Temperature, dissolved oxygen, conductivity and $\mathrm{pH}$ were measured with a multiparametric sensor (Horiba U-10). Samples for Biochemical Oxygen Demand $\left(\mathrm{BOD}_{5}\right)$, Chemical Oxygen Demand (COD), $\mathrm{P}-\mathrm{PO}_{4}{ }^{-3}, \mathrm{~N}-\mathrm{NO}_{3}{ }^{-}, \mathrm{N}-\mathrm{NO}_{2}{ }^{-}$and $\mathrm{N}-\mathrm{NH}_{4}{ }^{+}$were collected at each site using $500 \mathrm{~mL}$ bottles. For inorganic nutrients, samples were filtered through Sartorious GF/C filters in situ before transport to the laboratory at $4{ }^{\circ} \mathrm{C}$. Inorganic phosphate, nitrite, and ammoniacal nitrogen were determined colorimetrically by standard methods (American Public Health Association, 1981); nitrate was reduced to nitrite before colorimetric measurement
Table 1

List of the sampling sites showing their nearest urban centers, their coordinates (Lat. = latitude and Long. = longitude), the\% impervious surface (\%Imp.) of their surrounding areas and the number of times each site was visited $(\mathrm{N})$.

\begin{tabular}{|c|c|c|c|c|c|}
\hline Nearest city & Code & Lat. $\left({ }^{\circ} \mathrm{S}\right)$ & Long. $\left({ }^{\circ} \mathrm{W}\right)$ & \% Imp. & $\mathrm{N}$ \\
\hline Buenos & ArroAgui & $34^{\circ} 49^{\prime} 35.29^{\prime \prime}$ & $58^{\circ} 34^{\prime} 45.62 "$ & 12.20 & 6 \\
\hline \multirow[t]{20}{*}{ Aires } & ArroCanu & $34^{\circ} 54^{\prime} 53.39^{\prime \prime}$ & $58^{\circ} 37^{\prime} 53.87^{\prime \prime}$ & 7.91 & 5 \\
\hline & ArroCanu1 & $35^{\circ} 0^{\prime} 41.22^{\prime \prime}$ & $58^{\circ} 42^{\prime} 34.78^{\prime \prime}$ & 7.91 & 6 \\
\hline & ArroCanu2 & $34^{\circ} 55^{\prime} 28.34^{\prime \prime}$ & $58^{\circ} 36^{\prime} 35.21^{\prime \prime}$ & 7.91 & 6 \\
\hline & ArroCeb & $35^{\circ} 3^{\prime} 16.34^{\prime \prime}$ & $58^{\circ} 46^{\prime} 59.16^{\prime \prime}$ & 10.14 & 5 \\
\hline & ArroChac & $34^{\circ} 52^{\prime} 55.24^{\prime \prime}$ & $58^{\circ} 40^{\prime} 3.83^{\prime \prime}$ & 14.24 & 6 \\
\hline & ArroChac1 & $34^{\circ} 54^{\prime} 17.93^{\prime \prime}$ & $58^{\circ} 46^{\prime} 2.5^{\prime \prime}$ & 14.24 & 5 \\
\hline & ArroCild & $34^{\circ} 40^{\prime} 47.6^{\prime \prime}$ & $58^{\circ} 26^{\prime} 25.33^{\prime \prime}$ & 69.13 & 8 \\
\hline & ArroMora & $34^{\circ} 47^{\prime} 47.87^{\prime \prime}$ & $58^{\circ} 38^{\prime} 10.75^{\prime \prime}$ & 11.19 & 6 \\
\hline & ArroMora1 & $34^{\circ} 50^{\prime} 16.4^{\prime \prime}$ & $58^{\circ} 50^{\prime} 2.65^{\prime \prime}$ & 11.19 & 5 \\
\hline & ArroRod & $34^{\circ} 59^{\prime} 10.5^{\prime \prime}$ & $58^{\circ} 53^{\prime} 3.48^{\prime \prime}$ & 8.58 & 5 \\
\hline & ArroSCat & $34^{\circ} 44^{\prime} 8.12^{\prime \prime}$ & $58^{\circ} 28^{\prime} 49.04^{\prime \prime}$ & 33.52 & 7 \\
\hline & AutoRich & $34^{\circ} 44^{\prime} 50.6^{\prime \prime}$ & $58^{\circ} 31^{\prime} 19.81^{\prime \prime}$ & 16.83 & 6 \\
\hline & DepuOeste & $34^{\circ} 43^{\prime} 0.7^{\prime \prime}$ & $58^{\circ} 30^{\prime} 28.51^{\prime \prime}$ & 16.79 & 7 \\
\hline & MatyRuta3 & $34^{\circ} 55^{\prime} 26.22^{\prime \prime}$ & $58^{\circ} 43^{\prime} 16.75^{\prime \prime}$ & 16.79 & 6 \\
\hline & PteAvell & $34^{\circ} 38^{\prime} 17.09^{\prime \prime}$ & $58^{\circ} 21^{\prime} 24.52^{\prime \prime}$ & 69.13 & 6 \\
\hline & PteColor & $34^{\circ} 43^{\prime} 35.8^{\prime \prime}$ & $58^{\circ} 28^{\prime} 58.15^{\prime \prime}$ & 16.79 & 7 \\
\hline & PteLaNor & $34^{\circ} 42^{\prime} 17.14^{\prime \prime}$ & $58^{\circ} 27^{\prime} 41.11^{\prime \prime}$ & 69.13 & 6 \\
\hline & PteUribu & $34^{\circ} 39^{\prime} 37.66^{\prime \prime}$ & $58^{\circ} 25^{\prime} 5.74^{\prime \prime}$ & 69.13 & 6 \\
\hline & PteVicto & $34^{\circ} 39^{\prime} 43.24^{\prime \prime}$ & $58^{\circ} 23^{\prime} 19.14^{\prime \prime}$ & 69.13 & 6 \\
\hline & RLP-Taxco & $34^{\circ} 49^{\prime} 35.72^{\prime \prime}$ & $58^{\circ} 37^{\prime} 1.2^{\prime \prime}$ & 16.79 & 5 \\
\hline La & B1 & $34^{\circ} 50^{\prime} 58.99^{\prime \prime}$ & $58^{\circ} 10^{\prime} 54.98^{\prime \prime}$ & 86.11 & 2 \\
\hline \multirow[t]{11}{*}{ Plata } & B2 & $34^{\circ} 50^{\prime} 8.02^{\prime \prime}$ & $58^{\circ} 10^{\prime} 21^{\prime \prime}$ & 76.55 & 2 \\
\hline & B3 & $34^{\circ} 48^{\prime} 7.99^{\prime \prime}$ & $58^{\circ} 7^{\prime} 28.99^{\prime \prime}$ & 88.22 & 2 \\
\hline & DC1 & $35^{\circ} 54^{\prime} 9^{\prime \prime}$ & $58^{\circ} 1^{\prime} 35^{\prime \prime}$ & 89.33 & 2 \\
\hline & DC2 & $35^{\circ} 53^{\prime} 35.99^{\prime \prime}$ & $581^{\prime} 23.02 "$ & 56.12 & 2 \\
\hline & DC3 & $35^{\circ} 52^{\prime} 36.98^{\prime \prime}$ & $588^{\prime} 32.02^{\prime \prime}$ & 22.08 & 2 \\
\hline & Martin1 & $34^{\circ} 53^{\prime} 15^{\prime \prime}$ & $58^{\circ} 4^{\prime} 16^{\prime \prime}$ & 10.12 & 2 \\
\hline & Martin2 & $34^{\circ} 52^{\prime} 27.98^{\prime \prime}$ & $58^{\circ} 4^{\prime} 10.99 "$ & 26.11 & 2 \\
\hline & Martin3 & $34^{\circ} 51^{\prime} 34.99^{\prime \prime}$ & $58^{\circ} 3^{\prime} 50^{\prime \prime}$ & 18.62 & 2 \\
\hline & G1 & $34^{\circ} 58^{\prime} 48.94^{\prime \prime}$ & $58^{\circ} 3^{\prime} 8.96^{\prime \prime}$ & 82.44 & 1 \\
\hline & G2 & $34^{\circ} 57^{\prime} 53.1^{\prime \prime}$ & $58^{\circ} 0^{\prime} 17.57^{\prime \prime}$ & 46.08 & 1 \\
\hline & G3 & $34^{\circ} 53^{\prime} 21.73^{\prime \prime}$ & $57^{\circ} 59^{\prime} 34.94^{\prime \prime}$ & 10.33 & 1 \\
\hline \multirow[t]{6}{*}{ Tandil } & L1 & $37^{\circ} 17^{\prime} 58.63^{\prime \prime}$ & $59^{\circ} 7^{\prime} 50.92^{\prime \prime}$ & ND & 1 \\
\hline & L2 & $37^{\circ} 17^{\prime} 51.22^{\prime \prime}$ & $59^{\circ} 7^{\prime} 50.7 "$ & ND & 1 \\
\hline & L3 & $37^{\circ} 17^{\prime} 20.8^{\prime \prime}$ & $59^{\circ} 7^{\prime} 37.27^{\prime \prime}$ & ND & 1 \\
\hline & L4 & $37^{\circ} 17^{\prime} 0.89^{\prime \prime}$ & $59^{\circ} 7^{\prime} 37.09^{\prime \prime}$ & ND & 1 \\
\hline & L5 & $37^{\circ} 16^{\prime} 22.26^{\prime \prime}$ & $59^{\circ} 7^{\prime} 36.7 "$ & ND & 1 \\
\hline & L6 & $37^{\circ} 13^{\prime} 53.15^{\prime \prime}$ & $59^{\circ} 7^{\prime} 34.61^{\prime \prime}$ & ND & 1 \\
\hline
\end{tabular}

(Mackereth et al., 1978), and dissolved inorganic nitrogen (DIN) was calculated as the sum of nitrates, nitrites and ammonium.

\subsection{Benthic diatoms and chlorophyll-a}

In Pampean streams the principal substrate of the streambed is composed of fine sediments (clays and silts), where the epipelic biofilm develops. At each site, five subsamples of the surface layer $(0.5 \mathrm{~cm})$ of sediment were collected by pipetting (area $1 \mathrm{~cm}^{2}$ ), pooled, and preserved with $4 \%$ (v/v) formalin (Gómez et al., 2009). Diatoms were cleaned with $\mathrm{H}_{2} \mathrm{O}_{2}$, washed thoroughly with distilled water, and mounted on microscope slides with Naphrax ${ }^{\circledR}$. In order to determine the relative abundance of the diatom species in each sample, a total of 400 diatom valves were examined under an Olympus BX 51 microscope at a magnification of $\times 1000$ with phase contrast and Normarski-DIC optics. For the determination of chlorophyll- $a$ water samples were filtered immediately with Sartorious $\mathrm{GF} / \mathrm{C}$ filters and were then transported to the laboratory in the dark at $4{ }^{\circ} \mathrm{C}$. Chlorophyll- $a$ was determined spectrophotometrically using 90\% (v/v) aqueous acetone after Clesceri et al. (1998).

\subsection{Macroinvertebrates}

Three sediment sample replicates were taken at each sampling site with an Ekman grab covering an area of $100 \mathrm{~cm}^{2}$. In the laboratory, the benthic samples were washed on a $500-\mu \mathrm{m}$-mesh sieve 


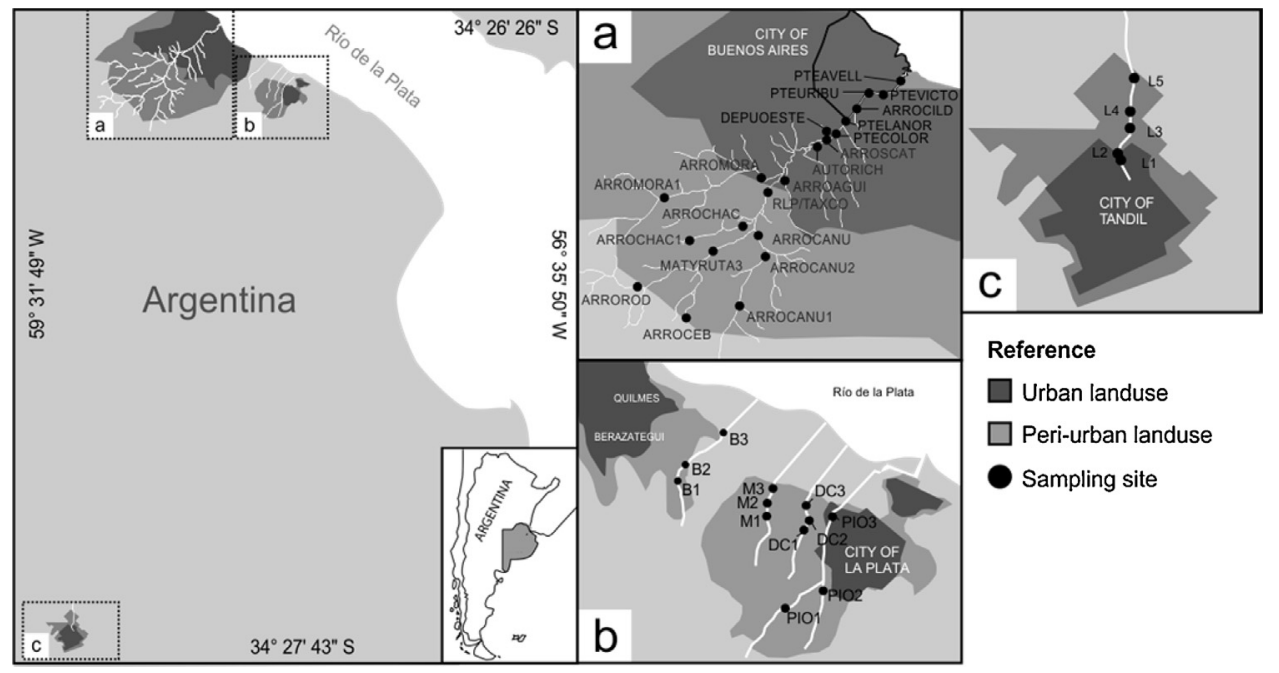

Fig. 1. Location of the sampling sites and the urban and peri-urban land uses of their surrounding areas.

and stained with erythrosin B. The invertebrates were sorted out from the particulate sediments under a stereoscopic microscope.

\subsection{Biotic indices}

For both the diatom and the macroinvertebrate communities, Shannon-Wiener's diversity index (Shannon and Weaver, 1949) and Pielou's evenness index (Pielou, 1969) were calculated. Specifically for the diatoms, the Pampean Diatom Index (IDP, Gómez and Licursi, 2001) was calculated, which ranges from 0 (samples with the best water quality) to 4 (samples with the worst water quality). For macroinvertebrates, the Biotic Pampean Index (IBPAMP, Rodrigues Capítulo et al., 2001) was calculated, which ranges from 0 (samples with the worst quality) to over 13 for samples from near pristine streams. The correlation between the habitat index and the IDP and IBPAMP was tested since they are regional indices designed specifically for the macroinvertebrate and diatom communities in pampean streams (Gómez and Licursi, 2001; Rodrigues Capítulo et al., 2001).

\subsection{Habitat sampling and candidate metrics}

At each site the habitat sampling procedure consisted of establishing a $100 \mathrm{~m}$-long reach with a $30 \mathrm{~m}$ width from the waterline to both riversides (Fig. 2). The reach length was subdivided in ten parcels by the use of visual markers (flags, colored sticks). The impervious surface percentage was also calculated for each site by the use of a geographic information system (GIS), considering a $300 \mathrm{~m}$ long surface starting upstream of the site and a $50 \mathrm{~m}$ buffer on each side, and classifying the land use based on Landsat TM imagery and land use maps of the area. Roads, houses, parking lots, and all non-green surfaces were considered an "impervious" surface.

A series of candidate metrics relating to habitat quality were measured at each reach, considering the characteristics of Pampean urban streams. Candidate metrics were classified into four groups: Instream, River banks, Riparian zone and Geomorphological alterations (Table 2). Metrics within the first three groups were evaluated as the presence or absence of a certain attribute in each parcel, to facilitate their assessment in the field. Metrics in the geomorphological alterations group were evaluated as one of three possibilities considering the whole reach without parcels.

\section{Index construction}

Each metric was subjected to a range test, a redundancy test, and a responsiveness test (Stoddard et al., 2008, Whittier et al., 2007). Metrics that passed these selection criteria were included in the index. The relationship of each candidate metric with independent physical-chemical and biological variables was also examined.

\subsection{Range test}

If a metric's range of values is small, or if most values are identical, then the metric is unlikely to differentiate sites. We eliminated metrics that had very small ranges $(<10 \%)$, or when more than one third of the cases had values of zero.

\subsection{Redundancy test}

If two variables had a significant Pearson's correlation coefficient $(\mathrm{p}<0.05)$ they were considered redundant. The variable with the lower $F$ value was then eliminated.

\subsection{Responsiveness test}

The ability of candidate metrics to distinguish between the least and most impaired sites was tested by conducting one-way analyses of variance (Whittier et al., 2007). For this purpose, sites were classified $a$ priori by their water quality and the impervious surface percentage into three categories, using the 75th and 25th percentiles in the variables (Gómez et al., 2012; Kane et al., 2009). Those cases that had values that fell within the 75th percentile lower concentrations of $\mathrm{P} \mathrm{P}-\mathrm{PO}_{4}{ }^{+3}, \mathrm{~N}-\mathrm{NO}_{3}{ }^{-}, \mathrm{N}-\mathrm{NO}_{2}{ }^{-}, \mathrm{N}-\mathrm{NH}_{4}{ }^{+}$, $\mathrm{BOD}_{5}$ and COD of the entire data set, and had an impervious surface percentage lower than 25th percentile were included in the "least impaired" category. Sites that had values that fell within the 25th percentile higher concentrations of those physical-chemical variables, and had higher than 75th percentile impervious surface percentages were included in the "most impaired" category. A third category was a dummy used for the samples in between those values. To confirm the samples within each category, they were classified with a discriminant analysis (DA), using these variables as predictors (Sloane and Morgan, 1996). This analysis has been identified as an acceptable statistical method for the development of indices of biotic integrity and can be used to identify variables that can discriminate between levels of degradation (Barbour et al., 


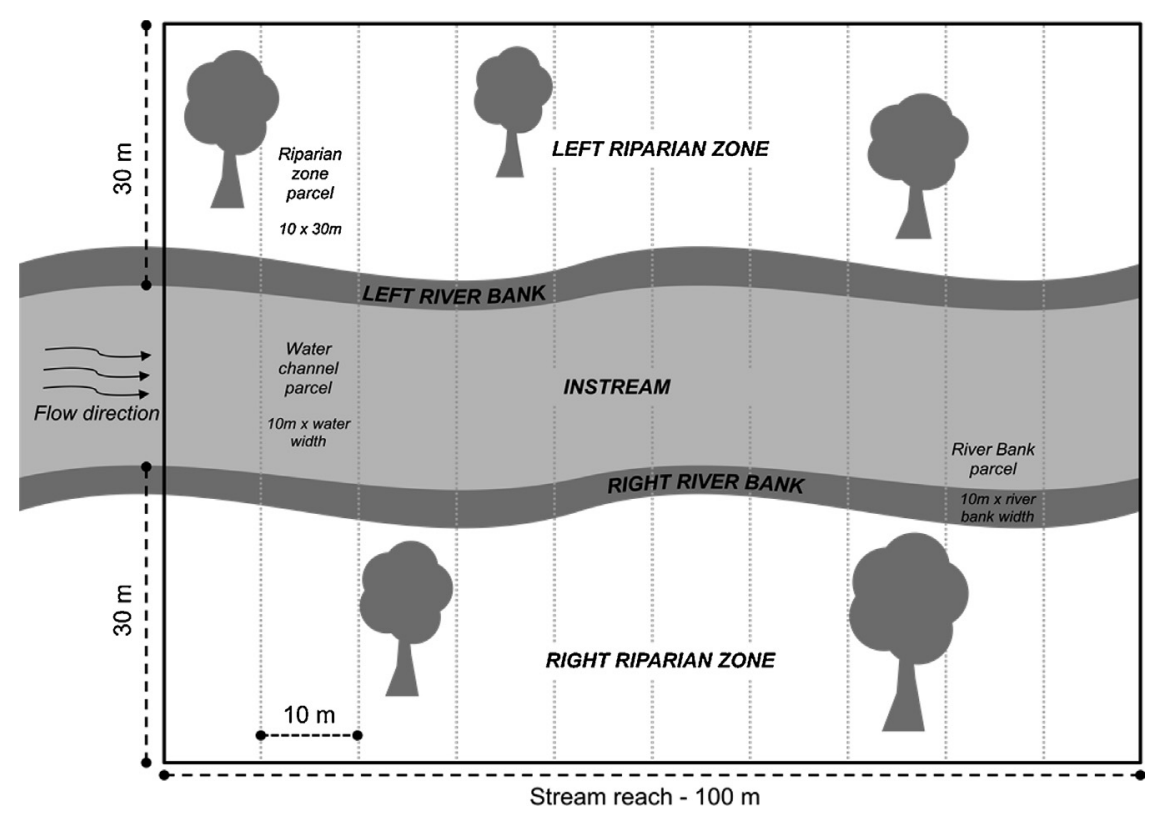

Fig. 2. Diagram of the scales used to measure the four metric groups (instream, river banks, riparian zone and geomorphology).

Table 2

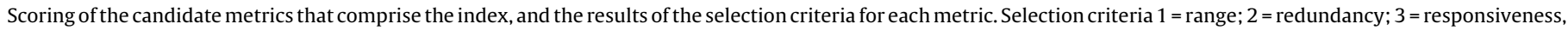
where $(+)$ passed, $(-)$ not passed, $\left({ }^{*}\right) \mathrm{p}<0.05$. The "index" column highlights those metrics that are included in the index.

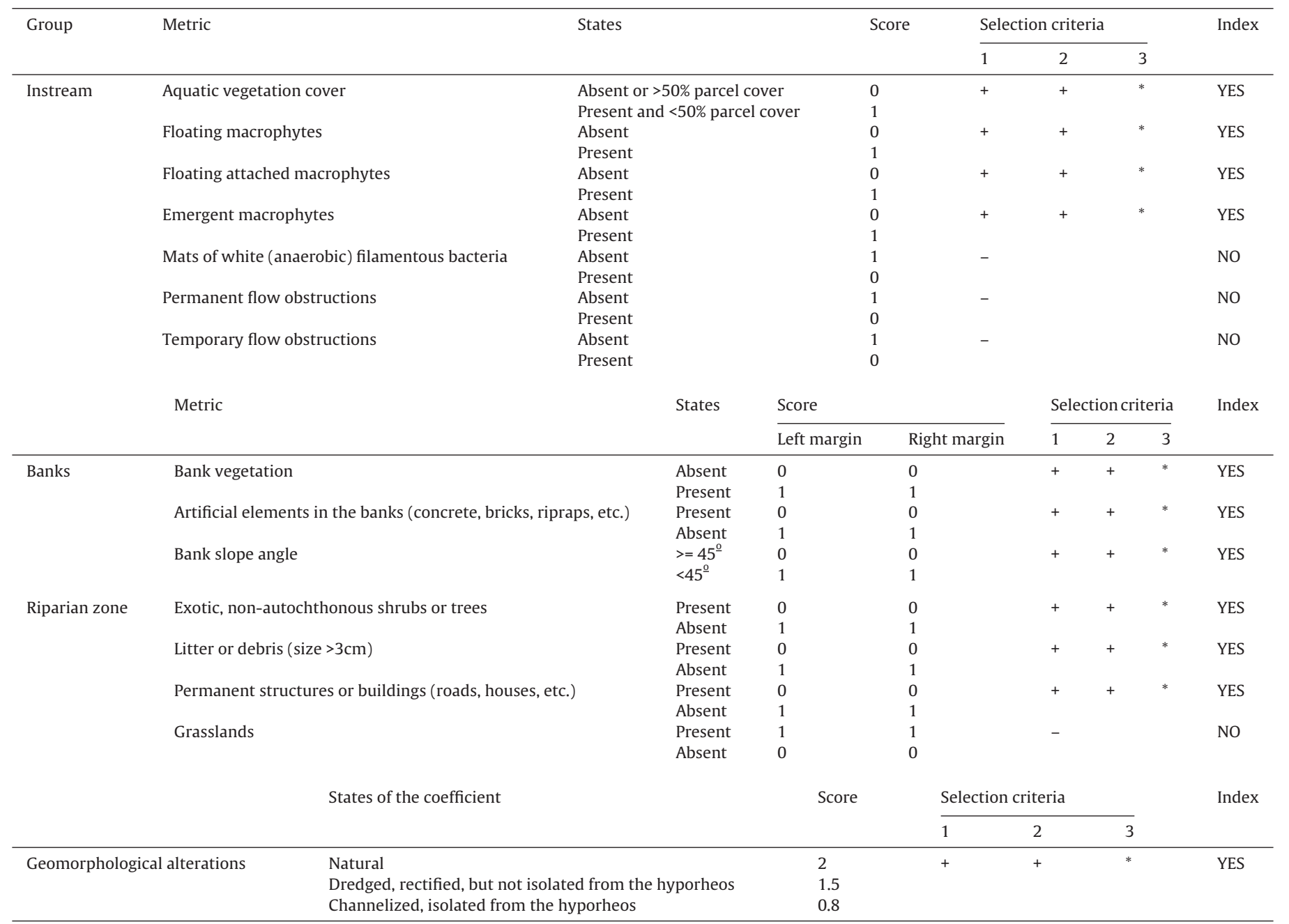


1999). After the DA was conducted, the cases that were retained in the "least impaired" (16 cases) and "most impaired" (10 cases) categories were used to test responsiveness of all the metrics and of the final index.

\subsection{Relationship with physical-chemical and biological data}

To test how the index responded to the physical-chemical variables related to water and habitat quality, a Principal Component Analysis (PCA) with varimax rotation was conducted. Only components with eigenvalues $>1.0$ were included in the analysis. Prior to PCA, appropriate transformations were performed $(\log x+1)$ to approximate the data to a normal distribution, if necessary. Also, the relationship between the metric groups with the physicalchemical, biological and watershed variables were analyzed using Spearman's correlation analysis.

\subsection{Metric selection and scoring}

From the 16 candidate metrics, only 11 were retained in three groups after the selection criteria were applied (Table 2). The scoring of each metric was done considering as ceiling the 95th percentile of the distribution of values, and as floor the 5th percentile of the distribution of values, and interpolated linearly to yield values between 0 and 10 .

The total scores for each metric group ranged from 0 to 4 in the instream group, and from 0 to 3 in both the river bank and riparian zone groups, with higher values representing a better habitat quality. Since metrics for the river bank and riparian zone are quantified
For the USHI, it was opted to reduce the seasonal variation from affecting the index significantly, by reducing the weight of those metrics with the highest variation between seasons. For each metric, the coefficient of variation (standard deviation/mean) between seasons and within seasons for each site was calculated. Those metrics with the highest variations between seasons had their values divided by an integer, selected so that the coefficient of variation was similar to their variation within seasons, and lower than $50 \%$ variation. This was the case for those metrics associated with the vegetation cover (the instream metrics, bank vegetation and exotic trees). The weight reduction of those variables associated with the vegetation development allows the USHI to be calculated at a site and, regardless of the season of the year in which the sampling takes place, the category of the habitat quality for that site remains the same.

For convenience when interpreting the final scores, the index gets ultimately divided by 10 to rescale it between 0 (worst habitat quality) and 10 (best habitat quality).

\section{Habitat index calculation}

The values obtained for each side of the stream in both the river bank metric and the riparian zone groups were averaged, to obtain ten values for each metric for the entire reach. A sample field form is included in Appendix A. The metrics in the instream group, the bank vegetation metric and the exotic trees metric had their weights reduced in the index to account for their seasonal variation, as explained in Materials and Methods. The index value is then calculated as follows:

$$
U S H I=\frac{(\left(\frac{\overbrace{A V C+F U M+F A M+E M M}}{8}\right)+\overbrace{\left(\frac{B V G}{4}+B S E+B S A\right)}^{\text {GROUP1 }}+\overbrace{\left(\frac{E X T}{4}+L I T+P E R\right)}^{\text {GROUP2 }}) * G A C}{10}
$$

Where USHI = Urban Stream Habitat Index for the assessed reach Group 1: Instream metrics

$\mathrm{AVC}=\%$ of aquatic vegetation cover

FUM = Floating macrophytes

$\mathrm{FAM}=$ Floating attached macrophytes

EMM $=$ Emergent macrophytes

Group 2: Bank metrics

$\mathrm{BVG}=$ Bank vegetation

$\mathrm{BSE}=$ Artificial elements in the banks

$\mathrm{BSA}=$ Bank slope angle

Group 3: Riparian zone metrics

EXT $=$ Exotic, non-autochthonous shrubs or trees

LIT $=$ Litter or debris

PER $=$ Permanent structures or buildings

$\mathrm{GAC}=$ Geomorphological alterations coefficient. hyporheos (by dredging, sinuosity reductions, etc.), or a value of 2 if the stream channel maintains its natural sinuosity and connectivity to the hyporheos. The values for this coefficient were selected $a$ priori so that the completely channelized sites would have an index value of near zero, considering that in those sites the fluvial habitat was severely degraded.

\subsection{Seasonal variation}

Indices that include biological communities are usually influenced by seasonal variation (e.g. Šporka et al., 2006; Chainho et al., 2007; Leunda et al., 2009). So that this variability does not influence judgment as to whether or not a site is degraded, it can be dealt with by adding correction factors (e.g. Hilsenhoff, 1988a,b), by including such seasonality in the construction of the index (e.g. Linke et al., 1999), or by directly defining a season in which to conduct the sampling, which is not always possible to control in an environmental assessment.

\subsection{Habitat index categories}

The habitat index ranges from 0 (worst habitat quality) to 10 (best habitat quality). We established five categories of habitat status that indicate the different degrees of environmental impairment, and we suggest the use of different color codes that can be used for habitat quality mapping (Table 3 ).

\section{Results}

The habitat index was able to significantly distinguish those least and most disturbed sites $(\mathrm{p}<0.05)$

The PCA results, where the first two axes explain $49.5 \%$ of the total variation of the data, show that the index increases with the dissolved oxygen concentration and the $\mathrm{pH}$, and decreases with 
Table 3

Habitat index categories, their color codes for graphical representation, and the number of cases from the data set that corresponded to each category.

\begin{tabular}{llll}
\hline Habitat index value & Status & Color code & \# of cases \\
\hline$<2$ & Very bad habitat quality & Red & 23 \\
$\geq 2-4$ & Bad habitat quality & Orange & 42 \\
$\geq 4-6$ & Moderate habitat quality & Yellow & 44 \\
$\geq 6-8$ & Good habitat quality & Green & 24 \\
$\geq 8-10$ & Very good habitat quality & Blue & 25 \\
\hline
\end{tabular}

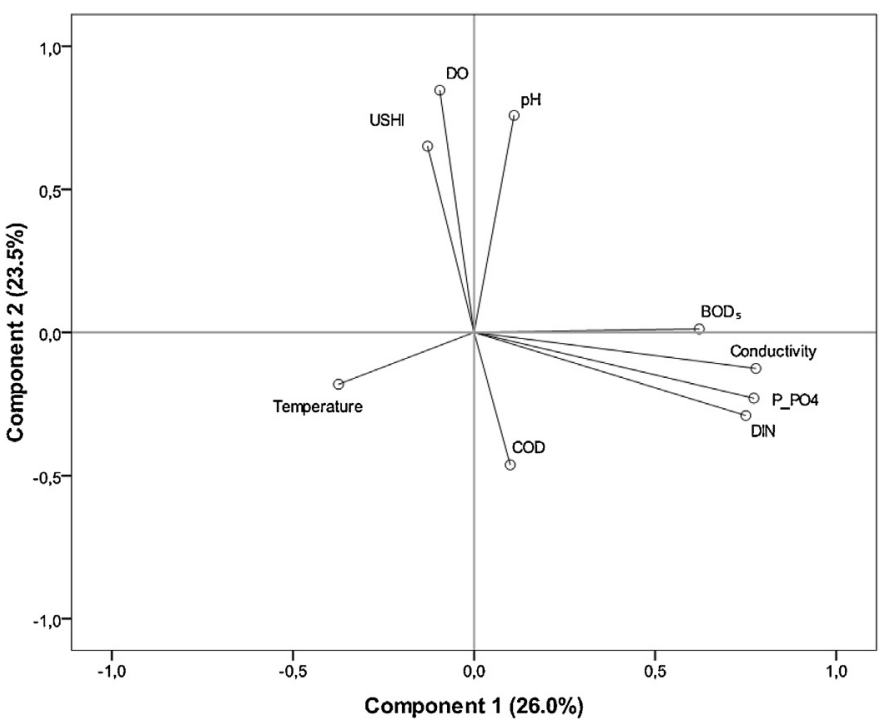

Fig. 3. Plot of the first two components as a result of the PCA analysis, with their corresponding percentage of explained variation. The variables include the USHI and the main water quality variables examined.

higher conductivity, DIN, P-PO The USHI correlates positively $(\mathrm{p}<0.05)$ with the IBPAMP index, the diversity and equitability of diatoms and macroinvertebrates, the dissolved oxygen concentration, and the chlorophyll- $a$ content (Table 4). It negatively correlates with the percentage of impervious surface and with the IDP index.

The instream metric group had a significant positive correlation $(\mathrm{p}<0.05)$ with the dissolved oxygen concentration $(\mathrm{r}=0.429)$, the IBPAMP index $(r=0.352)$, and the diversity $(r=0.444$, ), and equitability of macroinvertebrates $(r=0.201)$. Negative correlations were also found between this group and the IDP index and the percentage of impervious surface $(\mathrm{r}=-0.656)$.

The river banks metric group was positively correlated to the species richness $(r=0.250)$, diversity $(r=0.243)$ and equitability of diatoms $(r=0.205)$, the dissolved oxygen concentration $(r=0.344)$, the IBPAMP index $(r=0.322)$, and the diversity $(r=0.470)$ and equitability of macroinvertebrates $(r=0.284)$. It was negatively correlated to the IDP index $(r=-0.223)$, the conductivity $(r=-0.190)$ and the percentage of impervious surface $(r=-0.382)$.

The riparian zone metric group was positively correlated to the species richness of diatoms $(r=0.206)$ and the IBPAMP index $(r=0.277)$, while being negatively correlated to the conductivity $(\mathrm{r}=-0.169)$, the concentrations of $\mathrm{P}-\mathrm{PO}_{4}{ }^{-3}(\mathrm{r}=-0.192), \mathrm{N}-\mathrm{NH}_{4}{ }^{+}$ $(\mathrm{r}=-0.209), \mathrm{N}-\mathrm{NO}_{2}{ }^{-}(\mathrm{r}=-0.208)$ and $\mathrm{BOD}_{5}(\mathrm{r}=-0.212)$.

The mean index values for each site in the studied area show that $41.2 \%$ of the sites have a bad or very bad habitat quality, $27.8 \%$ a moderate habitat quality, while $31 \%$ have a good or very good habitat quality. The mean index values and the mean values for each of the three metric groups for each site are shown in Fig. 4.

The results also show that considering the instream metrics separately, $74 \%$ of the cases analyzed have a very bad quality, while
Table 4

Correlation coefficients of the USHI with the physical-chemical and biological variables, and with each of the metrics that are included the index $\left({ }^{*} p<0.05\right)$.

\begin{tabular}{|c|c|c|}
\hline Physical-chemical variables & $\mathrm{N}$ & USHI \\
\hline Temperature $\left({ }^{\circ} \mathrm{C}\right)$ & 146 & 0.001 \\
\hline $\mathrm{pH}$ & 146 & 0.130 \\
\hline Conductivity ( $\left.\mathrm{mS} . \mathrm{cm}^{-1}\right)$ & 146 & -0.094 \\
\hline Dissolved Oxygen (mg. $\left.\mathrm{L}^{-1}\right)$ & 140 & $0.474^{*}$ \\
\hline $\mathrm{P}-\mathrm{PO}_{4}{ }^{-3}\left(\mathrm{mg} . \mathrm{L}^{-1}\right)$ & 152 & -0.022 \\
\hline $\mathrm{N}-\mathrm{NO}_{-3}\left(\mathrm{mg} \cdot \mathrm{L}^{-1}\right)$ & 143 & 0.050 \\
\hline $\mathrm{N}-\mathrm{NO}_{-2}\left(\mathrm{mg} \cdot \mathrm{L}^{-1}\right)$ & 149 & -0.100 \\
\hline $\mathrm{N}-\mathrm{NH}_{+4}\left(\mathrm{mg} \cdot \mathrm{L}^{-1}\right)$ & 152 & -0.026 \\
\hline $\operatorname{DIN}\left(\mathrm{mg} \mathrm{L}^{-1}\right)$ & 147 & $-0.162^{*}$ \\
\hline $\mathrm{BOD}_{5}\left(\mathrm{mg} \mathrm{L}^{-1}\right)$ & 106 & 0.013 \\
\hline $\operatorname{COD}\left(\mathrm{mg} \mathrm{L}^{-1}\right)$ & 100 & $0.046^{*}$ \\
\hline$\%$ impervious surface & 128 & $-0.610^{*}$ \\
\hline \multicolumn{3}{|l|}{ Biological variables } \\
\hline IDP index & 125 & $-0.356^{*}$ \\
\hline \# of diatom species & 125 & $0.208^{*}$ \\
\hline Diatom diversity (bits ind ${ }^{-1}$ ) & 125 & $0.267^{*}$ \\
\hline Diatom equitability & 125 & $0.240^{*}$ \\
\hline Chlorophyll- $a\left(\mathrm{mg} \mathrm{L}^{-1}\right)$ & 128 & $0.263^{*}$ \\
\hline IBPAMP index & 145 & $0.336^{*}$ \\
\hline Macroinvertebrate diversity (bits ind ${ }^{-1}$ ) & 145 & $0.507^{*}$ \\
\hline Macroinvertebrate equitability & 145 & $0.304^{*}$ \\
\hline \multicolumn{3}{|l|}{ USHI Metrics } \\
\hline Bank vegetation & 158 & $0.757^{*}$ \\
\hline Artificial elements in the banks & 158 & $0.553^{*}$ \\
\hline Bank slope angle & 158 & $0.647^{*}$ \\
\hline Exotic trees or shrubs & 158 & $0.580^{*}$ \\
\hline Litter & 158 & $0.676^{*}$ \\
\hline Permanent structures & 158 & $0.450^{*}$ \\
\hline Aquatic vegetation cover & 158 & $0.471^{*}$ \\
\hline Floating macrophytes & 158 & $0.389^{*}$ \\
\hline Floating attached macrophytes & 158 & $0.235^{*}$ \\
\hline Emergent macrophytes & 158 & $0.383^{*}$ \\
\hline
\end{tabular}

there are no cases with a very good quality. The riparian zone metrics measured show that $38 \%$ of the cases have a very good riparian zone quality while $18 \%$ have a very bad quality; and as for the banks metrics, most cases have a very good quality, and only $10 \%$ have a very bad quality. Most sites were dredged or partially channelized $(\mathrm{GAC}=1.5)$, and only one site was completely channelized $(\mathrm{GAC}=0.8)$.

According to the results, over $70 \%$ of the sites presented problems associated with the cover of macrophytes and the presence of the different forms (instream metric group). The cases that exhibited a bad or very bad quality in the banks and riparian zone metric group reached $12 \%$ and $29 \%$ respectively.

\section{Discussion}

The metric selection process to build the USHI index retained eleven indicators to assess the fluvial habitat in lowland streams exposed to urban impacts. These metrics relate to the macrophyte cover and its functional forms, the bank deterioration and the riparian zone quality, which are relevant for the river functions and particularly for the flora and fauna that inhabit them.

In a review of over 50 river habitat characterization methods the channel and riparian zone features were found to be more extensively covered than floodplain characteristics (Fernández et al., 2011). Particularly, the most commonly recorded features are bank stability, channel substrate, the presence of artificial structures, riparian vegetation structure, channel dimensions, flow types or flow status, adjacent land uses and bars. The USHI includes most of these features, also incorporating geomorphological alterations, such as the dredging or channelization of the streambed, to account for the effects of the loss of connectivity of the stream to the 


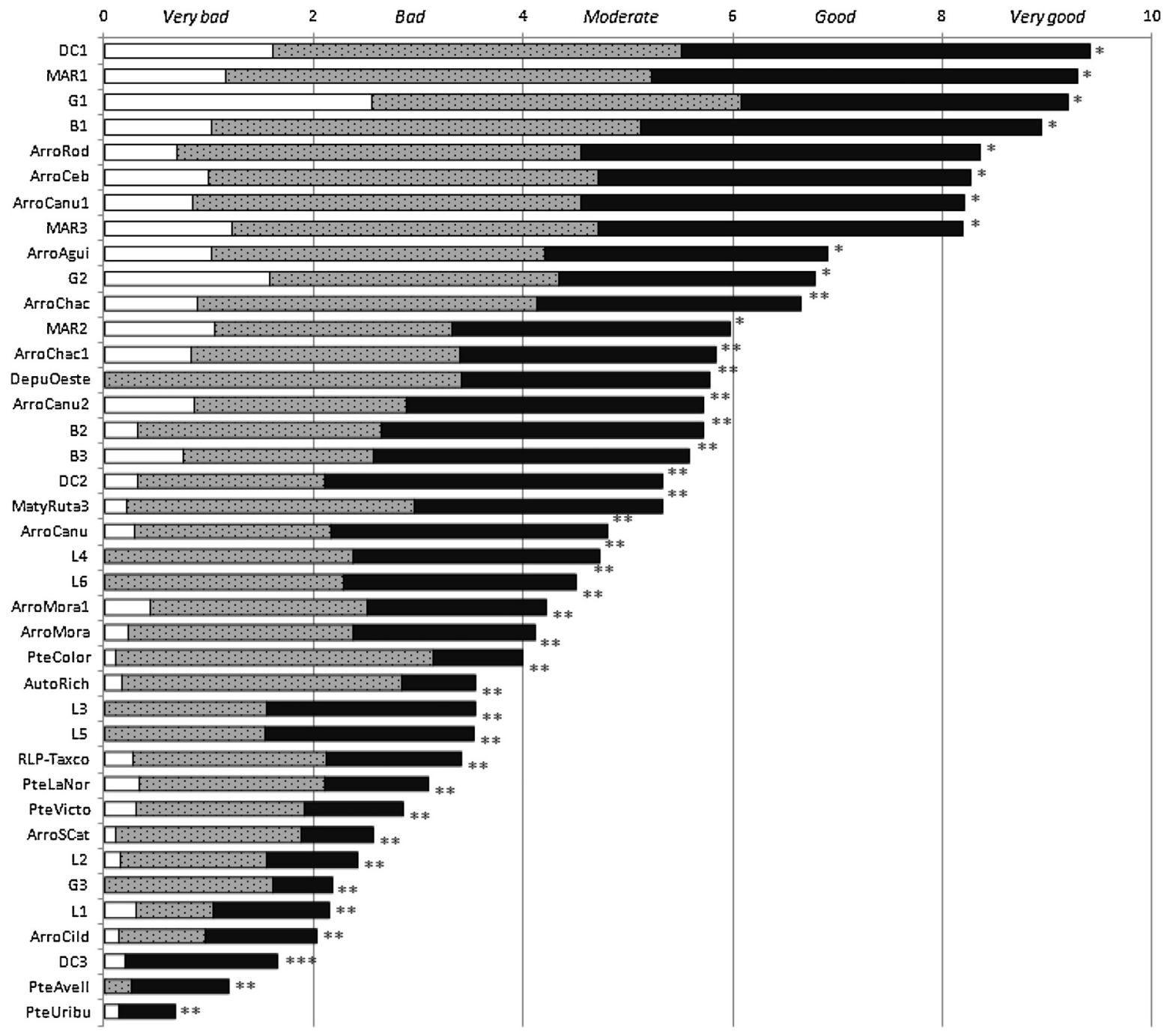

$\square$ Instream $\square$ Banks $\square$ Riaparian Zone

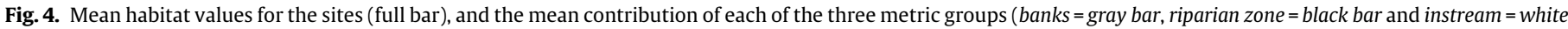

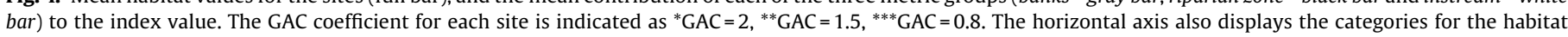
quality (very bad, bad, moderate, good, very good).

hyporheos and the physical modifications to the watershed that can alter the natural accumulation and erosion dynamics, reducing the environmental heterogeneity. Channel incision and simplification, including reduction in hyporheic flow (Grimm et al., 2005) and hydrologic isolation from riparian vegetation (Groffman et al., 2003) often have important effects on several instream ecological processes (Allan, 2004). The weighing of these geomorphological alterations in the index, especially to assess watercourses with high risks of flooding that can affect the urban centers that they run through, emphasizes the indicator value of this tool particularly in rehabilitation programs.

The USHI correlates significantly with several parameters related to the water quality, the watershed characteristics and the biotic descriptors, and its value increases with an improvement in water quality. Among the physical-chemical variables, the index correlates positively with the dissolved oxygen concentration, and negatively with the impervious surface percentage and the chemical oxygen demand, which indicates that the more urbanized areas correspond with a more degraded fluvial habitat. This is also consistent with the values obtained for the diatom and macroinvertebrate communities. The correlation of the habitat index with the IDP and
IBPAMP indices shows that the USHI reflects the biotic integrity in these watercourses. The IDP acquires higher values in more polluted environments (Gómez and Licursi, 2001), particularly by nutrients and organic matter, while the IBPAMP index gets lower values in those environments.

Despite the complexity of river habitats, a wide array of methodologies have been proposed for characterizing these habitats at a range of spatial scales in order to meet different objectives (Mc Ginnity et al., 2005), such as land use planning, conservation and restoration programs and environmental regulations.

Among the habitat evaluation systems most widespread, the River Habitat System (Raven et al., 2002), the "système d'évaluation de la qualité du milieu physique" (SEQ-PHYSIQUE, Agences de l'Eau and Ministère de l'Environnement, 1998) and the LAWA protocol (LAWA, 2000) were compared by Raven et al. (2002), and recorded similar values of hydromorphological characteristics (such as stream geometry, longitudinal and transversal profile, available substrates, vegetation and organic debris, erosion and sedimentation characteristics). However, the use of those already established protocols in lowland streams of the Pampean region has proven to be unreliable, since some parameters included in the 
protocols are not relevant for these watersheds, particularly due to the differences in riparian vegetation.

The results show that the main causes of the habitat quality detriment in the cases analyzed are mainly related to the bad quality of the instream metrics, followed by the riparian zone and the stream banks. Most cases have a very bad quality when the instream metrics are considered, showing that the aquatic vegetation in the studied reaches is highly degraded, and restoration or rehabilitation practices that aim at improving the habitat quality should include a greater focus in improving the environmental conditions that favor the development of healthier macrophyte assemblages. It is also noteworthy that most sites visited had been dredged or partially channelized, a procedure that greatly diminishes the benthic diversity (e.g. Lewis et al., 2001; Licursi and Gómez, 2009).

From the multiple methodologies used to develop tools for environmental monitoring (Stoddard et al., 2008; Whittier et al., 2007; Muttil and Chau, 2007; Wang et al., 2014, among many others), the USHI was built with a traditional approach, such as the one employed for the QBR index (Munné et al., 2003).

The objective of the USHI was to have a simple, practical monitoring tool to be incorporated in research aimed at evaluating the ecological status of lowland streams. Unlike other indices that evaluate the quality of the physical habitat through the use of the fish or macroinvertebrate communities (Meng et al., 2009; Diaz et al., 2004; Harrison and Whitfield, 2006), the USHI index uses indicators that do not have the complexity of the sampling and analyses that those communities require. The USHI only requires the information assessed in the field, without the need of specialized equipment or taxonomy experts for its application. The independence of the index from the seasonal variation also constitutes an advantage in environmental assessments, which cannot always be planned to be conducted in a particular season of the year.
The variables measured to calculate the USHI represent common signs of habitat degradation in urban streams worldwide: channelization, dredging, paving of the alluvial valley, the removal of macrophytes or the introduction of exotic trees in the riparian zone are common management practices directly related to urbanization. Although the USHI would represent a useful tool for the management of Pampean streams, after further testing and adaptation it could represent a useful tool in other urban environments exposed to similar human impacts.

\section{Conclusions}

The Urban Stream Habitat Index (USHI), presented in this article, represents a suitable tool for habitat assessment for the lowland Pampean streams. It is based on the information provided by 11 metrics in three metric groups (instream, banks and riparian zone). Differently from biotic indices based on macroinvertebrates or diatoms, all metrics can be measured in the field without the need of a specialist to identify the biota, and the index correlates well with several water quality variables and with other biotic indices that do require a more dedicated approach. Future developments for fluvial indices should consider the use of habitat related variables and the integration of spatial heterogeneity.

\section{Acknowledgements}

This study was funded by CONICET Project PIP 296, UNLPCONICET Project PIO 13420130100004CO, and UNLP project N736. We would like to particularly thank Lic. Jorge Donadelly for the nutrient analyses, Roberto Jensen for his valuable contribution to the fieldwork campaigns, and Lic. Estefanía Paz for her help with the macroinvertebrate indices. The present article is scientific contribution number 971 of the Institute of Limnology "Dr. Raúl A. Ringuelet" (ILPLA, CCT-La Plata CONICET, UNLP). 


\section{Appendix A. Sample field form for the calculation of the USHI}

Sample field form for the calculation of the USHI

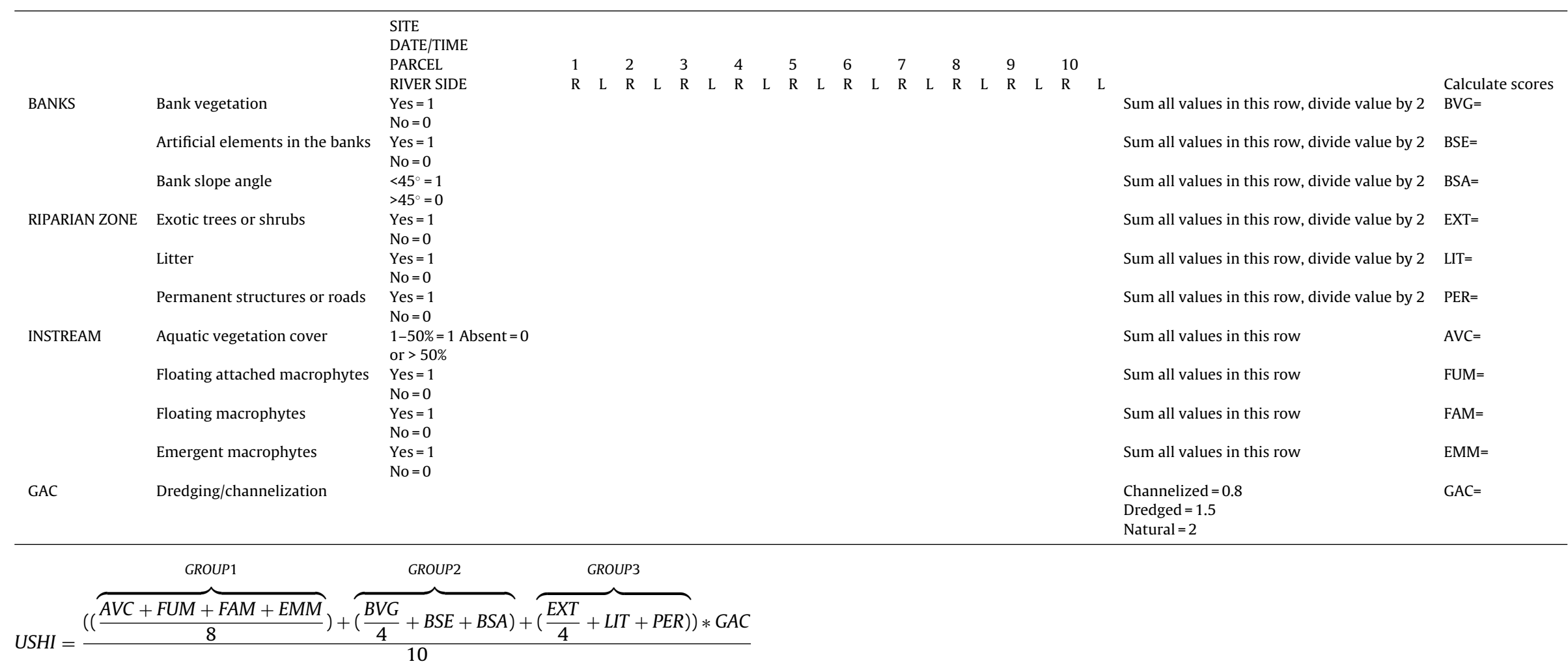




\section{References}

Aadland, L.P., 1993. Stream habitat types: their fish assemblages and relationship to flow. North Am. J. Fish. Manage. 13 (4), 790-806.

Agences de l'Eau and Ministère de l'Environnement, 1998. SEQ-Physique: a system for the evaluation of the physical quality of watercourses.

Allan, J.D., 2004. Landscapes and riverscapes: the influence of land use on stream ecosystems. Annu. Rev. Ecol. Evol. Syst., 257-284.

American Public Health Association (APHA), 1981. Standard Methods for the Examination of Water and Wastewater: Selected Analytical Methods Approved and Cited by the United States Environmental Protection Agency. American Water Works Association and Water Pollution Control Federation, Washington, p. 1325

Armengol, J., 1998. Efectos ecológicos del dragado y vaciado del embalse de Barasona. Limnetica 14, 17-33.

Barbour, M.T., Gerritsen, J., Snyder, B.D., Stribling, J.B., 1999. Rapid Bioassessment Protocols for Use in Streams and Wadeable Rivers. USEPA, Washington.

Bonada, N., Prat, N., Munné, A., Plans, M., Solà, C., Álvarez, M., Pardo, I., Moyà, G., Ramon, G., Toro, M., Robles, S., Avilés, J., Suárez, M.L., Vidal-Abarca, M.R., Mellado, A., Moreno, J.L., Guerrero, C., Vivas, S., Ortega, M., Casas, J., Sánchez-Ortega, A., Jáimez-Cuéllar, P., Alba-Tercedor, J., 2002. Intercalibración de la metodología GUADALMED. Selección de un protocolo de muestreo para la determinación del estado ecológico de los ríos mediterráneos. Limnética 21 (3-4), 13-35.

Borja, A., Bald, J., Franco, J., Larreta, J., Muxika, I., Revilla, M., Valencia, V., 2009. Using multiple ecosystem components, in assessing ecological status in Spanish (Basque Country) Atlantic marine waters. Mar. Pollut. Bull. 59 (1), $54-64$.

Bortone, S.A., 2005. Estuarine Indicators. CRC Press, Boca Raton, Florida (p. 507).

Brierley, G.J., Brooks, A.P., Fryirs, K., Taylor, M.P., 2005. Did humid-temperate rivers in the Old and New Worlds respond differently to clearance of riparian vegetation and removal of woody debris? Prog. Phys. Geogr. 29 (1), 27-49.

Buffagni, A., Erba, S., Cazzola, M., Kemp, J.L., 2004. The AQEM multimetric system for the southern Italian Apennines: assessing the impact of water quality and habitat degradation on pool macroinvertebrates in Mediterranean rivers. In: Integrated Assessment of Running Waters in Europe, Springer Netherlands, pp. 313-329.

Callow, P., Petts, G., 1994. The River Handbook: Hydrological and Ecological Principles (II). Blackwell Science.

Chainho, P., Costa, J.L., Chaves, M.L., Dauer, D.M., Costa, M.J., 2007. Influence of seasonal variability in benthic invertebrate community structure on the use of biotic indices to assess the ecological status of a Portuguese estuary. Mar. Pollut. Bull. 54 (10), 1586-1597.

Clesceri, L.E., AD, Greenberg, A.E., 1998. Standard methods for the examination of water and wastewater (No. 543/C634)

Cortelezzi, A., Sierra, M.V., Gómez, N., Marinelli, C., Capítulo, A.R., 2013. Macrophytes, epipelic biofilm, and invertebrates as biotic indicators of physical habitat degradation of lowland streams (Argentina). Environ. Monit. Assess. 185 (7), 5801-5815

Diaz, R.J., Solan, M., Valente, R.M., 2004. A review of approaches for classifying benthic habitats and evaluating habitat quality. J. Environ. Manage. 73, $165-181$

Davies, N.M., Norris, R.H., Thoms, M.C., 2000. Prediction and assessment of local stream habitat features using large-scale catchment characteristics. Freshw. Biol. 45 (3), 343-369.

Erftemeijer, P.L.A., Lewis III, R.R.R., 2006. Environmental impacts of dredging on seagrasses: a review. Mar. Pollut. Bull. 52, 1553-1572.

Fernández, D., Barquín, J., Raven, P.J., 2011. A review of river habitat characterisation methods: indices vs. characterisation protocols. Limnetica 30 (2), 217-234

Gómez, N., Cochero, J., 2013. Un índice para evaluar la calidad del hábitat en la Franja Costera Sur del Río de la Plata y su vinculación con otros indicadores ambientales. Ecol. Austral 23 (1), 18-26.

Gómez, N., Licursi, M., 2001. The pampean diatom index (IDP) for assessment of rivers and streams in Argentina. Aquat. Ecol. C, 173-181.

Gómez, N., Donato, J.C., Giorgi, A., Guasch i Padró, H., Mateo, P., Sabater, S., 2009. La biota de los ríos: los microorganismos autótrofos. In: Elosegui A; Sabater S. Conceptos y técnicas en ecología fluvial, Cap. 12, p. 219-242.

Gómez, N., Licursi, M., Bauer, D.E., Ambrosio, E.S., Capítulo, A.R., 2012. Assessment of biotic integrity of the coastal freshwater tidal zone of a temperate estuary of South America through multiple indicators. Estuaries Coasts 35 (5), 1328-1339.

Giorgi, A.D.N., Feijoó, C., Tell, G., 2005. Primary producers in a Pampean stream: temporal variation and structuring role. Biodivers. Conserv. 14, 1699-1718.

Grimm, N.B., Sheibley, R.W., Crenshaw, C.L., Dahm, C.N., Roach, W.J., Zeglin, L.H., 2005. N retention and transformation in urban streams. J. North Am. Benthol. Soc. 24 (3), 626-642.

Groffman, P.M., Bain, D.J., Band, L.E., Belt, K.T., Brush, G.S., Grove, J.M., Zipperer, W.C., 2003. Down by the riverside: urban riparian ecology. Front. Ecol. Environ. 1 (6), 315-321.

Gualdoni, C.M., Duarte, C.A., Medeot, E.A., 2011. Estado ecológico de dos arroyos serranos del sur de Córdoba, Argentina. Ecol. Austral 21, 149-162.

Harrison, T.D., Whitfield, A.K., 2006. Application of a multimetric fish index to assess the environmental condition of South African estuaries. Estuaries Coasts 29 (6), 1108-1120.
Hilsenhoff, W.L., 1988a. Seasonal correction factors for the biotic index. The great lakes entomologist. Mich. Entomol. Soc. 21 (1), 9-14.

Hilsenhoff, W.L., 1988b. Rapid field assessment of organic pollution with a family-level biotic index. J. North Am. Benthol. Soc. 7 (1), 65-68.

Jansen, A., Robertson, A., Thompson, L., Wilson, A., 2005. Rapid appraisal of riparian condition (Version 2). In: River and Riparian Land Management. Technical guideline 4A. Canberra, Land \& Water Australia.

Jowett, I.G., 1997. Instream flow methods: a comparison of approaches. Regul. Rivers: Res. Manage. 13 (2), 115-127.

Kane, D.D., Gordon, S.I., Munawar, M., Charlton, M.N., Culver, D.A., 2009. The planktonic index of biotic integrity (P-IBI): an approach for assessing lake ecosystem health. Ecol. Indic. 9, 1234-1247.

Kutschker, A., Brand, C., Miserendino, M.L., 2009. Evaluación de la calidad de los bosques de ribera en ríos del NO del Chubut sometidos a distintos usos de la tierra. Ecol. Austral 19, 19-34.

LAWA (Lainderarbeitsgemeinschaft Wasser), 2000. Federal State's Working Group 'Water', Germany (Ed.). Gewässerstrukturgütekartierung in der Bundesrepublik Deutschland -Verfahren für kleine und mittelgroße Fließgewässer. Bund/Lander-Ar- " beitsgemeinschaft Wasser, Berlin.

Leunda, P.M., Oscoz, J., Miranda, R., Ariño, A.H., 2009. Longitudinal and seasonal variation of the benthic macroinvertebrate community and biotic indices in an undisturbed Pyrenean river. Ecol. Indic. 9 (1), 52-63.

Lewis, M.A., Weber, D.E., Stanley, R.S., Moore, J.C., 2001. Dredging impact on an urbanized Florida bayou: effects on benthos and algal-periphyton. Environ. Pollut. 115, 161-171.

Licursi, M., Gómez, N., 2009. Effects of dredging on benthic diatom assemblages in a lowland stream. J. Environ. Manage. 90 (2), 973-982.

Linke, S., Bailey, R.C., Schwindt, J., 1999. Temporal variability of stream bioassessments using benthic macroinvertebrates. Freshw. Biol. 42 (3), 575-584.

Mackereth, F.J.H., Heron, J., Talling, J.F., 1978. Water Analysis: Some Revised Methods for Limnologists, vol. 36. Freshwater Biological Association, Ambleside.

Mayer, P.M., Todd, A.H., Okay, J.A., Dwire, K.A., 2010. Introduction to the featured collection on riparian ecosystems \& buffers. J. Am. Water Resour. Assoc. 46 (2), 207-210.

Mc Ginnity, P., Mills, P., Roche, W., Muller, M., 2002. Water Framework Directive: A Desk Study to Determine a Methodology for the Monitoring of the 'Morphological Condition' of Irish Rivers for the Water Framework Directive (2002-W-DS-9-M1). Environmental Protection Agency, Wexford (Ireland), 237 pp.

Meng, W., Zhang, N., Zhang, Y., Zheng, B., 2009. Integrated assessment of river health based on water quality, aquatic life and physical habitat. J. Environ. Sci. 21 (8), 1017-1027.

Miserendino, M.L., Brand, C., Di Prinzio, C., 2008. Assessing urban impacts on water quality, benthic communities and fish in streams of the Andes Mountains, Patagonia (Argentina). Water Air Soil Pollut. 194, 91-110.

Munné, A., Prat, N., Solá, C., Bonada, N., Rieradevall, M., 2003. A simple field method for assessing the ecological quality of riparian habitat in rivers and streams: QBR index. Aquat. Conserv.: Mar. Freshw. Ecosyst. 13 (2), 147-163.

Muttil, N., Chau, K.W., 2007. Machine-learning paradigms for selecting ecologically significant input variables. Eng. Appl. Artif. Intell. 20 (6), 735-744.

Newell, R.C., Seiderer, L.J., Hitchcock, D.R., 1998. The impact of dredging works in coastal waters: a review of the sensitivity to disturbance and subsequent recovery of biological resources on the sea bed. Oceanogr. Mar. Biol.: Annu. Rev. 36, 127-178.

Ordeix, M., Camprodom, J., Guixe, D., 2012. Metodología de diagnosis y evaluación del estado ecológico y la biodiversidad en res tauraciones flviales.Restauración y gestión ecológica fluvial. Ed. Centre Forestal Tecnòlogic de Catalunya, 12-22.

Pardo, I. Álvarez, M. Casas, J., Moreno, J.L., Vivas, S., Bonada, N., Robles, S., 2002. El hábitat de los ríos mediterráneos. Diseño de un índice de diversidad de hábitat. Limnetica 21 (3-4), 115-133.

Parsons, M., Thoms, M.C., Norris, R.H., 2004. Development of a standardised approach to river habitat assessment in Australia. Environ. Monit. Assess. 98 (1-3), 109-130.

Pedersen, M.L., Baattrup-Pedersen, A., 2003. National monitoring programme 2003-2009. Assessment methods manual (No. 21). Technical Report.-National Environmental Research Institute of Denmark.

Pielou, E.C., 1969. An introduction to mathematical ecology. An introduction to mathematical ecology.

Raven, P.J., Holmes, N.T. H., Dawson, F.H., Everard, M., 1998. Quality assessment using River Habitat Survey data.

Raven, P.J., Holmes, N.T.H., Charrier, P., Dawson, F.H., Naura, M., Boon, P.J., 2002. Towards a harmonized approach for hydromorphological assessment of rivers in Europe: a qualitative comparison of three methods. Aquat. Conserv.: Mar. Freshw. Ecosyst. 12, 405-424.

Raven, P.J., Holmes, N.T., Vaughan, I.P., Dawson, F.H., Scarlett, P., 2010. Benchmarking habitat quality: observations using River Habitat Survey on near-natural streams and rivers in northern and western Europe. Aquat. Conserv., S13-S30.

Rodrigues Capítulo, A.R., Tangorra, M., Ocón, C., 2001. Use of benthic macroinvertebrates to assess the biological status of Pampean streams in Argentina. Aquat. Ecol. 35 (2), 109-119.

Segnini, S., Chacón, M., 2005. Caracterización fisicoquímica del hábitat interno y ribereño de los ríos andinos en la cordillera de Merida, Venezuela. Ecotropicos $18(1), 38-61$ 
Shannon, C.E., Weaver, W., 1949. The mathematical theory of communication. University of Illinois Press 19 (7).

Sloane, D., Morgan, S.P., 1996. An introduction to categorical data analysis. Annu. Rev. Sociol., 351-375.

Šporka, F., Vlek, H.E., Bulánková, E., Krno, I.J., 2006. Influence of seasonal variation on bioassessment of streams using macroinvertebrates. Hydrobiologia 566 (1), 543-555.

Stoddard, J.L., Herlihy, A.T., Peck, D.V., Hughes, R.M., Whittier, T.R., Tarquinio, E., 2008. A process for creating multimetric indices for large-scale aquatic surveys. J. North Am. Benthol. Soc. 27 (4), 878-891.

Valipour, M., Sefidkouhi, M.A.G., Eslamian, S., 2015. Surface irrigation simulation models: a review. Int. J. Hydrol. Sci. Technol. 5 (1), 51-70.
Villamarín, C., Prat, N., Rieradevall, M., 2014. Caracterización física, química e hidromorfológica de los ríos altoandinos tropicales de Ecuador y Perú. Lat. Am. J. Aquat. Res. 42 (5), 1072-1086.

Wang, W.C., Xu, D.M., Chau, K.W., Lei, G.J., 2014. Assessment of river water quality based on theory of variable fuzzy sets and fuzzy binary comparison method. Water Res. Mange. 28 (12), 4183-4200.

Whittier, T.R., Hughes, R.M., Stoddard, J.L., Lomnicky, G.A., Peck, D.V., Herlihy, A.T. 2007. A structured approach for developing indices of biotic integrity: three examples from streams and rivers in the western USA. Trans. Am. Fish. Soc 136 (3), 718-735.

Yannopoulos, S.I., Lyberatos, G., Theodossiou, N., Li, W., Valipour, M., Tamburrino, A., Angelakis, A.N., 2015. Evolution of water lifting devices (pumps) over the centuries worldwide. Water 7, 5031-5060. 